\title{
SOCIO-ECNOMIC IMPACT OF SAURA TRIBE UNDER ODISHA TRIBAL EMPOWERMENT \& LIVEELIHOOD PROGRAMME, A STUDY OF GAJAPATI DISTRICT ODISHA
}

\author{
Pravat Kumar Ghadei ${ }^{1}$, Santosh Salve ${ }^{2}$, Dr. L.B Hota ${ }^{3}$, Sesadev Baliar Sing ${ }^{4}$ \\ ${ }^{1}$ UG - Research. Scholar, Social Work, Madhyanchal Professional University, Bhopal [M.P.] \\ ${ }^{2}$ Professors, Department of Arts. Social Science \& Humanity, Madhyanchal professional university, bhopal [m.p.] \\ ${ }^{3}$ Social development Specialist, World Bank Project, Bhubaneswar, PhD, IIT Kharagpur, \\ ${ }^{4}$ Professors, Sesadev Baliar Sing, Department of Social Work, Bijupatnaik College of Social Work, \\ Bhubaneswar, Odisha
}

\begin{abstract}
The state of odisha having 62 numbers of Tribe live, including 13 nos. of PVTG Tribe, about soura tribe odisha saura tribe (alternative name and spelling include Saora, savar \& sabar) are a munda ethnic group, They are also sometimes called Lanjia Souras due to their dress pattern of wearing ,This tribe most of found westernised of Eastern Ghat south Odisha, This PVTG tribe originated from (Austro-Astic Munda) Family Tribe, language are saura and oriya This tribe find three district like Gajapati, Bargad \& Rayagada and partly of koraput district of odisha, This study it clear that how the tribal community improved their livelihood through used natural resources like land, water, forest, other surrounding available material, and Government also allowed different scheme for improved their livelihood, The Odisha Tribal Empowerment \& Livelihoods Programme started effectively from January 2005 in the District of Gajapati the main objective Government improved the quality of life tribal Community.
\end{abstract}

Keywords: Tribal Livelihood are improved through Sustainable Livelihood Approach[SLA] are depend on Sound agriculture practice through Off farming /non- farm enterprise development and used surrounding natural recourses, for improved Overall Quality of Life.

\section{INTRODUCTION}

Tribal's are known to be the autochthonous people of the land. Tribal's are often referred to 'adivasi', 'vanvasi', 'pahari', 'adimjati', 'anusuchit janjati', etc. India has the second largest tribal population in the world. India, with a variety of ecosystems, presents a varied tribal population throughout its length and breadth depicting a complex cultural mosaic. India is a home for large number of tribal people, known as "ADVASI". Nearly all the tribal people of India have been in almost continuous contact with their neighbor, who lives by farming and a large number of specialized manual industries. The tribal people have rich traditions, cultures and heritage with unique life styles and customs. Despite some regional variation, the tribes share many common traits, including living in relative geographical isolation, and being relatively more homogeneous and more self-contained than the non-tribal social groups.

\subsection{Objective of the Study}

1. To understand the traditional pattern of livelihood of local communities.

2. To find out the changing pattern of livelihoods after intervention of Odisha Tribal Empowerment Livelihood Programme.

1.2 Methodology: The study best on direct interaction of tribal community under 12 Panchayat and 5 TSP (Tribal Sub plan ) block Gajapati District Under Odisha, I direct involved this study last three years for deeply understand the livelihood of tribe and government programme for improved livelihood this community, I used different sampling method, both qualitative and quantitative, questioner tools designed, hypotheses, FGD, Group discussion, etc. for objective gathering more information in field , source of data direct information to field and secondary information, 


\section{International Advanced Research Journal in Science, Engineering and Technology}

Vol. 8, Issue 10, October 2021

\section{DOI: $10.17148 /$ IARJSET.2021.81013}

1.2.1 Secondary data collection The sources of secondary data are the published and unpublished reports. Data from secondary sources were gathered from books, articles, journals, published reports, Census reports, and Government documents. Quantitative information with regard to land-holding, demographic aspects, cropping pattern and irrigation system were also collected from Panchayat profile and District Statistical Hand Book. The secondary sources like books, journals, articles, etc., also provided a picture of traditional source of livelihoods and their management system of Odisha.

\section{$>\quad$ Case study \\ $>\quad$ SAI ( Social Impact Study) \\ $>\quad$ FGD (Focused Grouped Discussion}

\section{Case study}

Case studies method involve in-depth research and study of individuals or groups. In other word this method is more study about a Group and Individual, Case study methods are commonly used in sociology, social sciences, and increasingly in information systems (is) research since the 1980s, Case study design is versatile and flexible; it can be used with any philosophical perspective (e.g., positivist, interpretive, or critical); it can also combine qualitative and quantitative data collection methods (Dubé\&Paré, 2003).

Case study research can involve a single case study or multiple case studies; and can take the strategy of an explanatory, exploratory or descriptive approach (Yin, 2011).

Data collection with be done with a significantly broad range of stakeholders, including:

1. Carrying out interviews, whether in person, individual informants or groups.

2. Observations, including the use of ethnographic methods.

3. Self-Administered Surveys.

4. Secondary analysis of existing data through national, international reports, journals and other sources.

Sampling research is of two types - probability sampling and non-probability sampling. Probability sampling is a sampling technique where a researcher sets a selection of a few criteria and chooses members of a population randomly. All the members have an equal opportunity to be a part of the sample with this selection parameter. In nonprobability sampling, the researcher chooses members for research at random. This sampling method is not a fixed or predefined selection process. This makes it difficult for all elements of a population to have equal opportunity to be included in a sample. Researchers use this sampling technique widely when conducting qualitative research, pilot studies, or exploratory research.

Judgmental sampling is a non-probability sampling technique where the researcher selects units to be sampled based on their knowledge and professional judgment. This type of sampling technique is also known as purposive sampling and authoritative sampling.

Questionnaire Method: A questionnaire is a research instrument that consist of a set of question for gathering all field information, through face to face, individual or group discussion.

Data collected through self-administered survey and the data will be tabulated and codified using MS excel and further analysis will be done with the help of new Version, Appropriate statistical analysis, study Factor Analysis will be applied. Factor analysis is a statistical method used to describe variability among observed, correlated variables in terms of a potentially lower number of unobserved variables called factors.

Hypothesis: This hypothesis study is a statement that introduces a research question proposed and an expected out come

\subsection{Study Area}

The project is conducted the Gajapati district of Odisha state. About Gajapati one of the 30 districts of Odisha, located South odisha, This District has been named after Maharaja Sri Krushna Chandra Gajapati Narayan Deo, the Ex-Raja Sahib of Paralakhemundi estate (the 1st Prime Minister of Odisha State), who is remembered for his contribution in formation of a separate Odisha

Covering an area of $3850 \mathrm{sq} \mathrm{km}$, Gajapati District lies between $18^{\circ} .6^{\prime}$ to $19^{\circ} .39^{\prime}$ North Latitude and $83^{\circ} .48^{\prime}$ to $84^{\circ} .08^{\prime}$ East Longitude. Climatic condition in the Gajapati District varies between 16 degree to 40 degree Celsius and the normal rainfall received is $1403.30 \mathrm{~mm}$. The District is surrounded by Andhra Pardesh in its South, Ganjam District in its East, Rayagada in its West and Kandhamal in its North. The soil and climate is suitable for plantation of crops and there is a great potential of horticulture development in the District. More than 60 percent of lands are situated in hilly terrain and high lands. Those are mainly suitable for horticulture. Other cultivable land are coming under medium lands (20 percent) and low lands (15 percent) category.

According to 2011 census Total ST population of the Gajapati District is 3,13,714 
Vol. 8, Issue 10, October 2021

\section{Geophysical Feature:}

DOI: $10.17148 /$ IARJSET.2021.81013

This ITDA covers mostly the hilly areas with varying altitudes from $609 \mathrm{~m}$ to $13464 \mathrm{~m}$. within the great line of the Eastern Ghats and featured by some of highest mountains of Odisha. Highest peak (Mahendragiri) $1500.53 \mathrm{~m}$. It has a forest area of 2351.11 sq. kms. The major/ minor forest products are timber, bamboo, Hill broom, Patalgaruda, Soap nut, B.Kaliakhali, Marsinga leaf, Dhatuki flowers, Kochila seeds, Genduli Gum, Siali leaves, Kath Alai etc. Where Odisha Tribal Empowerment \& Livelihood Programme cover 72385.993 of all 5 TSP block under Gajapati district the soil and climate is suitable for plantation crops and horticulture. More than $60 \%$ of lands are situated in hilly terrain, as high lands, mainly suitable for horticulture plantation. Other cultivable land belongs to the category of medium lands $(20 \%)$ and low lands (15\%).

Demography of OTELP Programme area , Gajapati District, Odisha State

\begin{tabular}{|c|c|c|c|c|c|c|}
\hline $\begin{array}{l}\text { SIN } \\
\text { o }\end{array}$ & Programme Coverage & Unit & Phase I & Phase II & Plus & Total \\
\hline 1 & No. of Villages & Nos. & 106 & 57 & 191 & 354 \\
\hline 2 & Treatable Area (in Ha.) & $\mathrm{Ha}$ & 21732.5 & 10206.74 & 40446.753 & 72385.993 \\
\hline \multirow{4}{*}{3} & Total Household & Nos. & 4825 & 2124 & 7509 & 14458 \\
\hline & ST Household & Nos. & 4806 & 2040 & 6772 & 13618 \\
\hline & SC Household & Nos. & 14 & 84 & 318 & 416 \\
\hline & OC Household & Nos. & 5 & 0 & 308 & 313 \\
\hline 4 & BPL Household & Nos. & 3073 & 1502 & NA & 4575 \\
\hline 5 & Landless Household & Nos. & 1151 & 469 & NA & 1620 \\
\hline 6 & $\begin{array}{l}\text { Vulnerable/Destitute } \\
\text { Households }\end{array}$ & Nos. & 1059 & 726 & 2537 & 4322 \\
\hline 7 & No of SHG. & Nos. & 381 & 144 & 664 & 1189 \\
\hline \multirow{4}{*}{8} & Population & Nos. & 24790 & 11078 & 38183 & 74051 \\
\hline & ST Population & Nos. & 25469 & 10897 & 35020 & 71386 \\
\hline & SC Population & Nos. & 65 & 418 & 1764 & 2247 \\
\hline & Others & Nos. & 26 & 0 & 1429 & 1455 \\
\hline
\end{tabular}

Source of information SC ST Department Govt. Odisha (OTELP Programme)

\section{MAP OF OTELP PROGRAMME UNDER GAJAPATI DISTRICT, ODISHA}

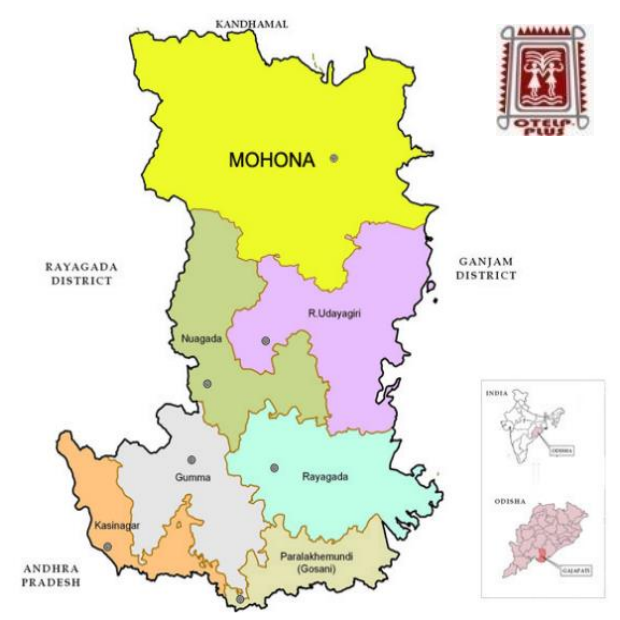

\section{Objective for Improved Livelihood}

To "enable the poor tribal households to sustainably ensure their livelihoods and food security through promoting a more efficient, equitable, self-managed, optimum sue of the natural resources, Offfarming/ non-farming enterprise development and accessing the rights and entitlements due to them

\section{Broad Objectives}

$>\quad$ To build their capacity of marginal groups

$>\quad$ To enhance the access of poor tribal people to natural resources and increase its productivity

$>\quad$ To encourage and facilitate off farm enterprises

$>\quad$ To ensure basic entitlements of tribal households

To achievement or Outcome of this study:-

$\circ \quad$ Build the capacity of marginal groups as individuals and grassroots institutions.

Enhance the access of poor tribal people to land, water and forests and increase the productivity of these resources in environmentally sustainable and socially equitable ways.

$\circ \quad$ Encourage and facilitate Off-Farm enterprise development based on the needs of poor tribal household.

- Monitor the basic food entitlements of tribal household and ensure their access to public food supplies. 


\section{International Advanced Research Journal in Science, Engineering and Technology}

Vol. 8, Issue 10, October 2021

DOI: $10.17148 /$ IARJSET.2021.81013

- Strengthen the institutional capacity of government agencies, panchayati Raj Institutions to work effectively for participatory poverty reduction with tribal communities.

- Encourage the development of a pro-tribal enabling environment through ensuring that legislation governing control and access to development resources by poor tribal households is implemented effectively and by recommending other policy improvements.

- Build on the indigenous knowledge and values of trials and blend these with technological innovations to ensure an speedier pace of development.

Sustainable Livelihood: This is a long term process for increase livelihood and save its future generation. It also focus about rural development, poverty reduction and environmental management. Under this approach we focused on Tribal area utilized the natural recourse like land, water forest and adopt new technique method of farming, as a result the income of individual and Group income improved.

\subsection{Situation Before OTELP Programme}

Schedules Tribes in Odisha State differ from one another in racial traits, language, social organization, cultural patterns, etc.

Before OTELP Plus Intervention in Gajapati District, the main problems of the tribal's are Poverty and exploitation. Economic, technological backwardness. Problems of assimilation with the non-tribal, population. Illiteracy, \& not getting Basic need,

In Other Words as per previous Survey Before OTELP Programme Intervention of Five Tribal Sub Plan Block [TSP] under Gajapati district. The tribal's are the most backward as because of their low literacy and primitive economy. Tribes are generally backward, economically as well as educationally. The situation is not uniform in all the parts .These differences can be seen in terms of hill tribes and plainsmen; between those who are engaged in forest-based economic pursuits and the ones who are employed as settled agriculturists Tribes exploitation, economic and technological backwardness, socio cultural handicaps - some problems which arise with the question of assimilation of these tribes with the mainstream/plains' populations.

\subsection{Despite these distinctions, some common problems of the tribal people are:}

1) Poverty and exploitation.

2) Economic and technological backwardness.

3) Socio-cultural handicaps.

4) Problems of assimilation with the non-tribal population.

\subsection{Economic Problems}

The tribal people had strong sense of community life. but into their life they are dominated by moneylender, Exchange the basic mode of economic relations. However they have $\mathrm{o}$ brought them under their control by extending loans at ex alienating them from land they cultivated. Indebtedness led to 2.3. Loss of Control over Natural Resources

Ownership and management over natural resources like, li

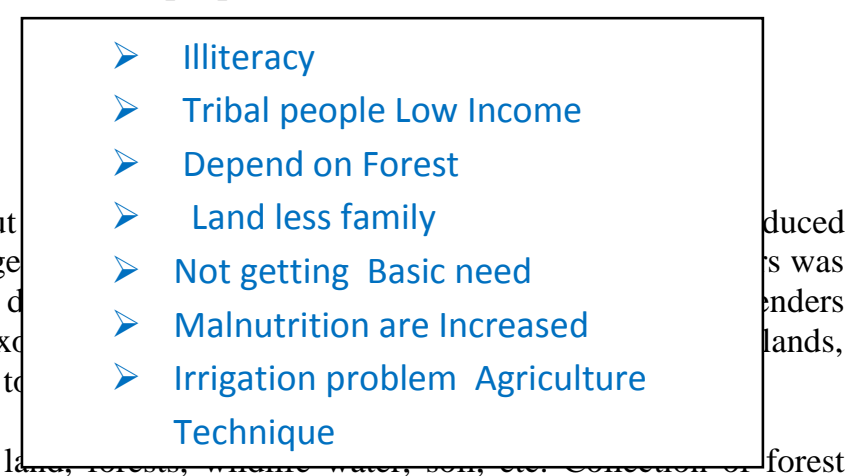
based products and living with forests, dependent on nature were the basic features of tribal resources. Indigenous peoples have an intuitive relationship with nature, a wealth of traditional knowledge, and have used natural resources for their livelihood.

Livelihood has been changed. Jungles, Forest disappeared in large amount, by Jangali Maphia

2.4 Poverty and Exploitation: Poverty refers to the condition of not having the means to afford basic human needs such as clean water, nutrition, health care, clothing and shelter. This is also referred to as absolute poverty. Relative poverty is the condition of having fewer resources or less income than others within a society or country, or compared to worldwide averages. Generally poverty is measured by Below Poverty Line (BPL) indices in tribes areas. Below Poverty Line is an economic benchmark and poverty threshold used by the government.

\subsection{Lack of Awareness about Government Schemes}

In the Indian context, scheduled tribes have the special provisions, constitutional rights for their social, economic and educational promotion. Recent tribal welfare schemes,

2.5.1 Subsistence Economy Tribal economy is characterized as subsistence oriented. The popular forms of subsistence economy are that of collecting,

2.5.2 Unemployment Forest is the main employment source of tribal workers in Gajapati district Tribes ,

2.5.3 Public health and nutrition of the tribal people were not aware, 
Vol. 8, Issue 10, October 2021

\section{DOI: 10.17148/IARJSET.2021.81013 \\ FINDING AND ANALYSIS}

\section{SOCIO-ECONOMIC DEVELOPMENT OF TRIBAL}

After OTELP Programme, intervention in Gajapati District, several success point changes achieved the socioeconomic development have brought immense change in the cultural pattern and life style of the Tribes. The State Governments are trying to focus on their life style. A series of multifarious developmental programmes relating, to livelihood, Drinking, water. Farming, Employment, through MGNREGA. Health and sanitation, education, environment, infrastructural development individual benefit schemes, etc. are found to be introduced this programme in the Tribe of Gajapati district Odisha State,

Under Odisha Tribal Empower \& Livelihood Programme, Tribal community through utilized Natural recourses like land, water, Forest, and N.T.F forest . They are changing their life style, Through Forest Value Addition Product, Individual support, being a entrepreneur under OTELP Programme different scheme this community are getting benefit and increased their Income,

OTELP Programme Support financial and training programme to Tribal Self Help Group (SHG) Farmers Group Youth club, Agriculture, Horticulture and Livestock Inputs. With Capacity Building Training Handholding support for increased their Income.

\section{SOURCE OF LIVELIHOODS}

The main source of livelihood are settled based farming both rabe and kharif season, agriculture are the backbone of the tribal people, through Odisha Tribal Empowerment \& Livelihood Programme, Govt. Provide support to tribal people farming for main objective over come to poverty, like free seed distribution, fertilizer other farming equipment , free goat rearing, poultry unity, Apiculture Farming other need based farming, free shop of tribal youth (EPVG), Community based training programme, are provided by this programme,

All forest product collected by Individual or Group, through this programme, product also selling through different Govt. agency.

\section{Agriculture \& Horticulture activities:-}

Farming is the main economical backbone of the Tribal community; mainly they depend on traditional methods of farming, under OTELP programme. We have given all handholding support, through convergence with MGNREGA and tribal developed funds like SCA to TSS, State Plan, RKVY, etc. For support to the tribal farmers various activities like providing irrigation, pump sets. Highbred seed organic compost, other necessary equipment, Expert farmers need best training with handholding support.

Agriculture Production and Irrigation:- KEY finding,

- $68 \%$ of the respondent report increase in productivity of various Agricultural crops compared to $75 \%$ of last Seven year

The land cultivation pattern in both programme and control villages are almost similar. However, the percentage of farmers cultivating land for both consumption and sale are more in case of programme villages in comparison to the control villages. In 2017-14: $56 \%$ families in programme villages cultivate land for both consumption and sale where as in $2020-21$, it is $68 \%$ and more focus was given upon the land used for sale purposes.

Cluster approach:- The concept of cluster approach was introduced in the year 2019-20 in OTELP Plus Programme area of Gajapati district, Odisha, where the farmer beneficiaries would be more beneficial by production of crops in large scale .this cluster approach in OTELP Plus paralakhemundi was implemented both block like R.udayagiri and mohana blocks of Gajapati district . Crops taken in cluster approach were cultivated in minimum area of 20 ha. as continue patches.

Crops like cabbage, tomato, brinjal, banana ,ginger \& turmeric, ragi, millet, paddy are cultivated through cluster approach where input support of seeds and fertilizers are given. This cluster approach was planned for both off farm and on farm activates which included poultry unit, goat unit, leaf stitching unit. These units are established by covering 100 beneficiaries' from nearby 2-3 villages. Through cluster approach there is better market linkage for the produce. Now farmer are interested to cultivation crops this approach.

Organic farming:- A way of livelihood -Under OTELP Plus we support farmer to used traditional; compost with Organic. agriculture is a holistic production management system, which promotes and enhances agro ecosystem health, including biodiversity, biological cycles and soil biological activity. 


\section{International Advanced Research Journal in Science, Engineering and Technology}

Vol. 8, Issue 10, October 2021

\section{DOI: 10.17148/IARJSET.2021.81013}

It emphasis the use of management practices in preference to the use of on farm inputs, taking in to account regional conditions locally adopted systems, Last three year its effect both block R.Udayagiri and Mohana Block farmers are getting more benefit in this farming.
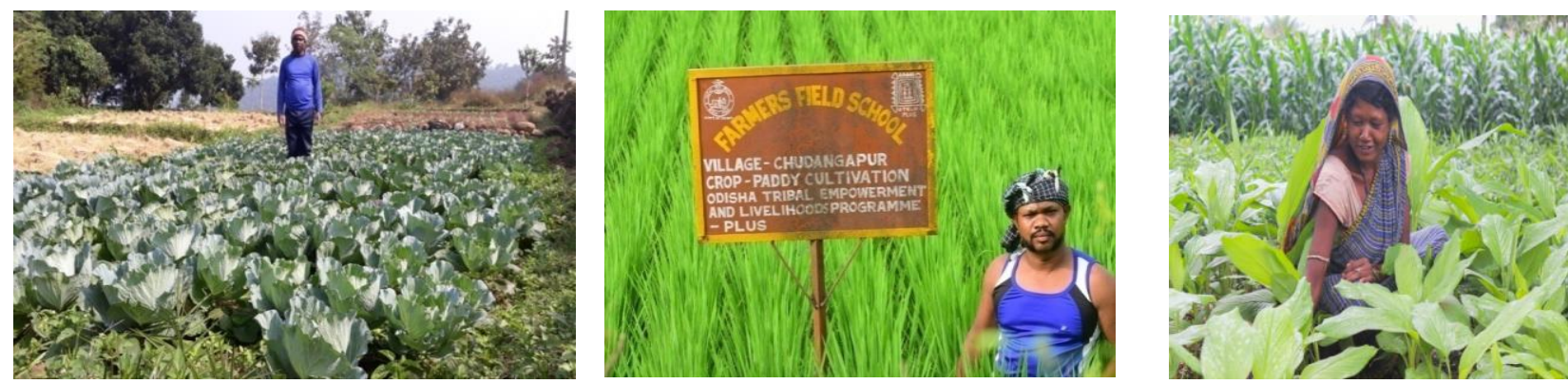

Farmers field School: - Farmers field school is a new initiative taken by OTELP Plus area block mohana and R.udayaagiri, this was launched in 2018-19 Financial year under OTELP Plus programme , the main o objective was to introduce new technology in farmers field in presence of the field staffs and to involve the nearby farmers through which they are motivated to continue the new practices of cultivation .

\section{Food Security:- KEY FINDING}

- $\quad 99 \%$ OF the families are having food security in programme villages

- The duration of food shortage in the programme villages is also lower than compare other village

While designing various livelihood interventions, the priority of the programme centres ensuring food security to the poor tribal households in the remote project villagers. The situation of these villages before the interventions of the programme was worst in comparison with the state and national averages. People striving for foods for more than eight months. The programme has intervened in promoting primary sector development, particularly the agriculture to increase the production at the village level and also to increase the cash income at the family level to enable financial access to food.

The below figure are present a seven year achievement report programme area in OTELP paralakhemundi this figure are explain after OTELP Programme intervention in programme village. The livelihood of Tribal community improved the income, same as lifestyle also change, this figure also explain the happiness among the tribe under Gajapati District, Odisha.

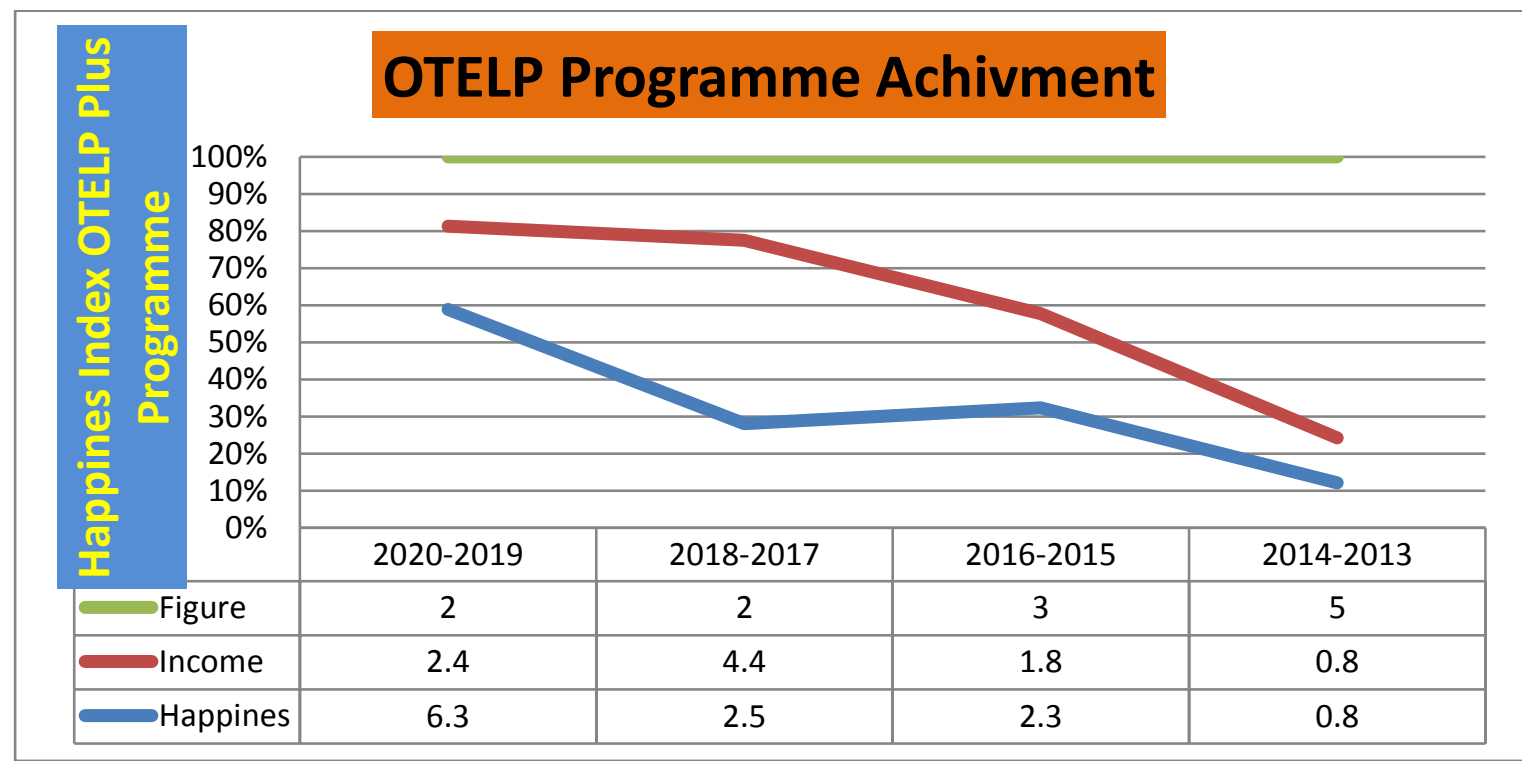


Vol. 8, Issue 10, October 2021

DOI: $10.17148 /$ IARJSET.2021.81013
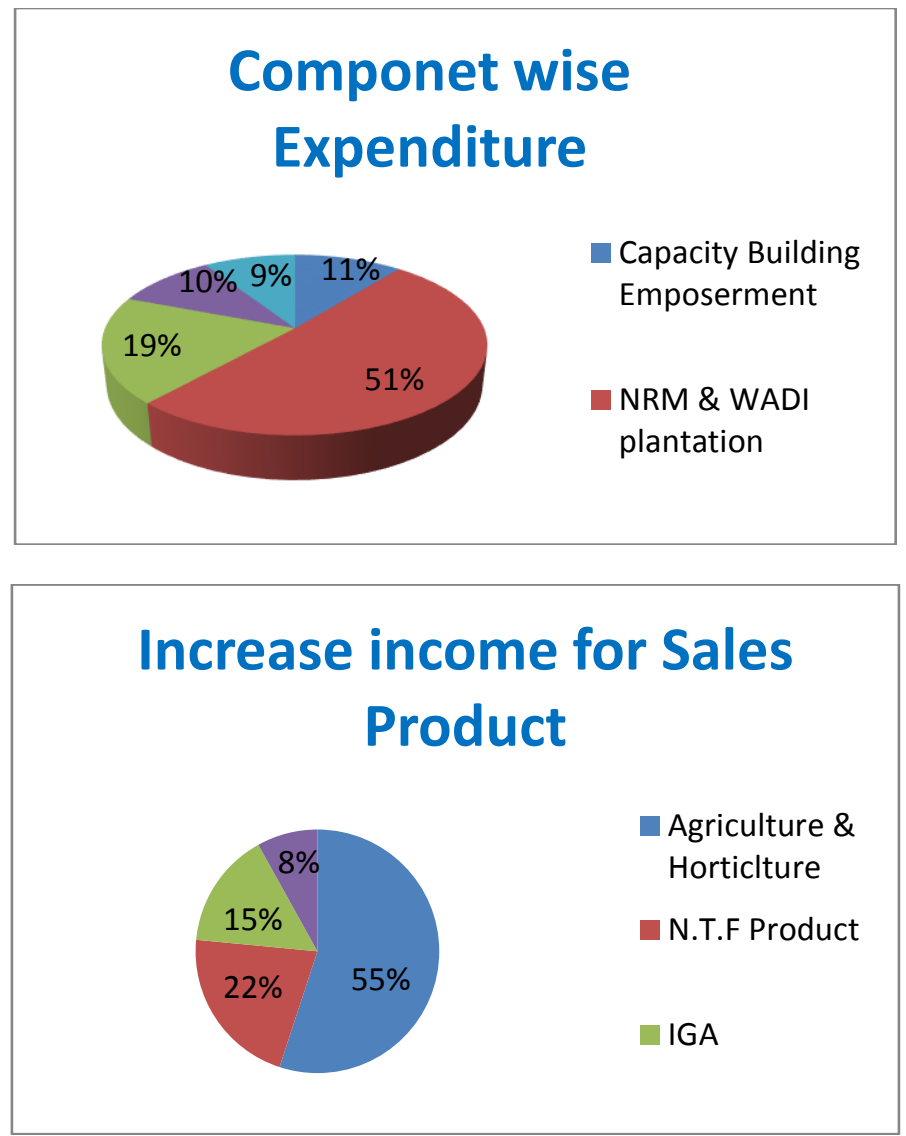

\section{Access to Market:-}

The programme are more selling of Tribal product like NTFP, IGA product with SHG and agriculture product with cooperation TDCC, ORMAS, and Other Agency, This study it is Observed that 55\% of the farmers have earned from the sale of the agriculture products in comparison to $47 \%$ of the last two . $92 \%$ of them have increased income from the sale of agriculture, NTF, IGA production in comparison to $50 \%$ of five year.

\section{CONCLUSION}

As compare Government are more emphasized to the tribe people for improved their quality of life. so Government allowed different scheme, programme for improved the income and quality of life of tribe community, OTELP Programme is a flagship programme of Government through this programme Government tray to improved all round of development of tribal community and enabling them to enhance their food security, increase their incomes and improve their overall quality of life through more efficient natural resource management more productive environmentally sound agricultural practices and through off-farm/non-farm enterprise development.

\section{REFERENCES:-}

Reference Odisha Tribal Livelihood Programme Government of Odisha Book,

Fernandes, Walter and Geeta Menon (eds) 1987. 'Tribal Women and Forest Economy', Indian Social Institute, New Delhi.

Gadgil, M. and F. Berkes. 1991. Traditional resource management system, Resource management and optimisation, 8 (3-4): 127-141.

Deepaika Thakur, Alpy Shama, Sanjay kr Uniyal Journy of ethnobiology and ethnomedicine Why they eat, what they eat, patterns of wild edible plants consumption in a tribal area of western Himalaya 13 (1), 1-12,20217

Gadgil, M. and R. Guha. 1990. Ecological prudence and modes of resource use. Centre for Ecological Science, Technical Report 59

Rajkishor Meher Livelihood, poverty and morbidity: a study on health and socio-economic status of the tribal population in Orissa, Journal of Health Management 9 (3), 343-367, 2007

Chambers, R. and Gordon Conway. 1991. Sustainable Livelihoods: Practical Concept for the 21st Century, IDS Discussion paper 296.

Fernandes, Walter, Geeta Menon and Philip Viegas 1984. 'Forests, Environment and Forest Dweller Economy in Orissa', Indian Social Institute, New Delhi, mimeo, pp 129-33.

Mishra, N. 2005. 'Eco-feminism: A global concern', Social welfare, 3-8.

Mishra, N. 2007. Participatory Water Management and Sustainable Tribal Livelihood: Study of a Pani Panchayat in Southern Orissa, Unpublished Thesis Submitted to University of Hyderabad, Hyderabad. Praduman kumar, Mrthuyuanjaya and Madan M Dey, 2007, Long term changes in India Food Basket and Nutrition, Economic and Political Weekly, Vol. 42, No. 35, pp: 3567-3572.

Roy Burman, B.K. 1993. 'Tribal development in world system perspective', Social change, 23 (2-3): 27-32.

Singh, B. 1992. 'Ground water resources and agricultural development strategy: Punjab experience', Indian journal of agricultural economics, 47 (1): $105-13$.

Krishna, S. 2004. Livelihood and Gender: Equity in Community Resource Management, Sage publication, New Delhi 